\title{
KARAKTERISASI ABU TERBANG PLTU CILACAP UNTUK MENURUNKAN KESADAHAN AIR DI DESA DARMAKRADENAN KECAMATAN AJIBARANG KABUPATEN BANYUMAS
}

\author{
Senny Widyaningsih*, Ely Setiawan, Tien Setyaningtyas \\ Program Studi Kimia, Fakultas Sains dan Teknik UNSOED \\ e-mail : sennysetiadi@yahoo.com
}

\begin{abstract}
Fly ash is an ash with smooth granular shape and black grey color. It is a waste material produced from the burning of coal. The contain of fly ash especially is silica and alumina that it can be used as adsorbent. As adsorbent, fly ash as used to decrease water hardness at Darmakradenan Village, Ajibarang District. The result showed that the porosity of fly ash was $13.6056 \%$, the water content was $0.055 \%$, adsorption capacity of iodium was $216.8975 \mathrm{mg} / \mathrm{g}$, and adsorption capacity of methylen blue was $0,3891 \mathrm{mg} / \mathrm{g}$. Fly ash could decrease total water hardness. The adsorption rise when contact time was added. Adsorption reached equilibrium at contact time 120 minutes with decreasion percentage $63.6363 \%$.
\end{abstract}

Keywords : fly ash, adsorption, water hardness

\section{PENDAHULUAN}

Abu terbang merupakan material oksida anorganik berwarna abu-abu kehitaman yang mengandung silica dan alumina aktif karena sudah melalui proses pembakaran pada suhu tinggi. Abu terbang merupakan sisa-sisa pembakaran batubara yang dialirkan dari ruang pembakaran melalui ketel berupa semburan asap.

Berdasarkan PP No. 85 Tahun 1999 tentang Perubahan Atas Peraturan Pemerintah No. 18 Tahun 1999 tentang Pengelolaan Limbah Bahan Berbahaya dan Beracun, abu terbang dikategorikan sebagai limbah B3 karena terdapat kandungan oksida logam berat yang akan mengalami pelindian secara alami dan mencemari lingkungan (Sunaryo dan Legowo, 2003). Penyumbang produksi abu terbang batubara terbesar adalah sektor pembangkit listrik.

Meningkatnya jumlah pembangunan PLTU berbahan bakar batubara di Indonesia, maka jumlah limbah abu terbang juga meningkat. PLTU Cilacap yang baru diresmikan penggunaannya dikhawatirkan akan mengancam kesehatan warga sekitarnya (Pikiran Rakyat, 2006). Menurut Pusat Studi Lingkungan dan Kebijakan Cilacap, abu terbang membutuhkan penanganan khusus, baik di tempat batubara digunakan atau di lokasi lain. Tingkat resiko penggunaan batubara bergantung pada sifat fisik dan radiologis dari abu terbang yang dihasilkan serta bagaimana abu terbang tersebut terdistribusi atau digunakan lagi.

Abu terbang telah dimanfaatkan untuk keperluan industri semen dan beton tetapi jumlahnya masih sangat sedikit. Sebagai adsorben abu terbang juga telah digunakan untuk mengadsorbsi ion-ion logam (Singh, 2005) serta zat warna (Wang, 2005). Pada penelitian ini abu terbang dimanfaatkan untuk mengurangi kesadahan air di Desa Darmakradenan Kecamatan Ajibarang yang sebagian besar daerahnya mengandung kapur dengan tingkat kesadahan 467,68 ppm sebagai $\mathrm{CaCO}_{3}$. Namun sebelumnya dilakukan karakterisasi terhadap abu terbang meliputi analisis komposisi, 
porositas, kadar air, daya serap terhadap iodium, dan daya serap terhadap metilen biru.

\section{METODE PENELITIAN}

\section{Alat dan Bahan}

Bahan yang digunakan dalam penelitian adalah abu terbang yang diambil dari PLTU Desa Karangkandri, Kec.Kesugihan, Kab.Cilacap Jawa Tengah, metilen biru, iodium, natrium tiosulfat, buffer $\mathrm{NH}_{4} \mathrm{Cl}$, EDTA, nheksana, $\mathrm{KI}, \mathrm{CaCO}_{3}$, dan indicator EBT.

Peralatan yang diperlukan adalah peralatan gelas yang biasa digunakan di laboratorium kimia, oven, tanur, shaker, XRF, dan spectrometer UV-Visible.

\section{Karakterisasi \\ Komposisi}

Analisis komposisi kimia abu terbang dilakukan menggunakan alat XRF.

\section{Porositas}

Piknometer kosong ditimbang $\left(\mathrm{w}_{1}\right)$, kemudian diisi penuh dengan $\mathrm{n}$ heksana dan ditimbang $\left(\mathrm{w}_{2}\right)$. Piknometer dengan bubuk sampel setinggi $1 / 4$ piknometer ditimbang $\left(\mathrm{w}_{3}\right)$ dan piknometer dengan bubuk sampel dengan n-heksana sampai penuh juga ditimbang $\left(\mathrm{w}_{4}\right)$, kemudian porositasnya dihitung dengan persamaan berikut :

$$
\begin{gathered}
V_{n-\text { heksana }}=\frac{w_{4}-w_{3}}{\rho_{n-\text { heksana }}} \\
D_{b u l k}=\frac{m}{V_{b}}=\frac{w_{3}-w_{1}}{V_{\text {pik }}-V_{n-\text { heksana }}} \\
D_{u}=\frac{w_{3}-w_{1}}{\left(w_{3}-w_{1}\right)-\left(w_{4}-w_{3}\right)} x\left(D_{L}-D_{A}\right)+D_{A} \\
\text { \%porositas }=\frac{D_{u}-D_{b u l k}}{D_{u}} \times 100 \%
\end{gathered}
$$

Keterangan :

$\mathrm{w}_{1}=$ berat piknometer kosong

$\mathrm{w}_{2}=$ berat piknometer $+\mathrm{n}$-heksana

$\mathrm{w}_{3}=$ berat piknometer + sampel

$\mathrm{W}_{4}=$ berat piknometer + sampel + n-heksana
$\mathrm{D}_{\mathrm{A}}=$ rapat massa udara $1,161 \mathrm{~g} / \mathrm{L}$

$D_{L}=$ rapat massa $n$-heksana $0,66 \mathrm{~g} / \mathrm{cm}^{3}$

\section{Kadar air}

Abu terbang ditimbang sebanyak $2 \mathrm{~g}$ ke dalam cawan porselin yang telah diketahui bobotnya. Cawan dimasukkan dalam oven yang diatur suhunya $105^{\circ} \mathrm{C}$ selama 3 jam kemudian didinginkan dalam desikator dan ditimbang.

Kadar air $(\%)=\frac{(a-b)}{b} \times 100 \%$

$\mathrm{a}=$ bobot arang mula-mula $(\mathrm{g})$

$\mathrm{b}=$ bobot arang setelah dikeringkan $(\mathrm{g})$

\section{Penentuan daya serap terhadap iodium}

Abu terbang ditimbang 0,5 g dan dipindahkan ke dalam wadah berwarna gelap dan tertutup, kemudian dimasukkan $50 \mathrm{~mL}$ larutan iodium $0,1 \mathrm{~N}$, dikocok selama 15 menit lalu disaring. Filtrat diambil sebanyak $10 \mathrm{~mL}$ kemudian dititrasi dengan larutan natrim tiosulfat 0,1 N. jika warna kuning larutan hilang, ditambahkan inikator kanji 1\%. Titrasi dilanjutkan sampai mendapatkan titik akhir (warna bitu tepat hilang).

Daya serap terhadap iodium $(\mathrm{mg} / \mathrm{g})=$ $\frac{\left(10-\frac{N x V}{0,1}\right)}{S} \times 12,69 \times 5$

$\mathrm{V}=$ larutan natrium tiosulfat yang diperlukan $(\mathrm{mL})$

$\mathrm{N}=$ normalitas larutan natrium tiosulfat $\mathrm{S}=$ bobot abu terbang ( $\mathrm{g}$ )

$12,69=$ jumlah iod untuk $1 \mathrm{~mL}$ larutan natrium tiosulfat $0,1 \mathrm{~N}$

\section{Penentuan daya serap terhadap biru metilen}

Abu terbang sebanyak $0,1 \mathrm{~g}$ dimasukkan dalam Erlenmeyer kemudian dititer dengan larutan biru metilen 0,1\% sambil dikocok selama 5 menit (sampai warna larutan yang diserap sama dengan warna peniter).

Daya serap terhadap biru metilen $(\mathrm{mg} / \mathrm{g})$ $=\frac{V x B J_{\text {larutan }}}{S}$ 
$\mathrm{V}=$ volume biru metilen yang diserap $(\mathrm{mL})$

$\mathrm{S}=$ bobot abu terbang $(\mathrm{g})$

\section{Aplikasi abu terbang}

\section{Penentuan waktu kontak}

Abu terbang sebanyak $0,1 \mathrm{~g}$ dimasukkan dalam $100 \mathrm{~mL}$ sampel air sadah dan diaduk dengan pengaduk magnetik selama 10,30,60,90,120,150,dan 180 menit. Masing-masing waktu dianalisis kesadahannya.

\section{Analisis kesadahan total sampel air sadah}

Sampel air sadah sebanyak $30 \mathrm{~mL}$ ditambahkan beberapa tetes $\mathrm{HCl}$ lalu dikocok. Sebanyak $25 \mathrm{~mL}$ sampel diambil lalu diencerkan menjadi $50 \mathrm{~mL}$. Larutan buffer $\mathrm{NH}_{4} \mathrm{Cl}$ sebanyak $2 \mathrm{~mL}$ dan indicator EBT ditambahkan dalam sampel. Larutan dititrasi sampai warna merah hilang menjadi biru. Kesadahan total air ditentukan dengan persamaan :

Kesadahan total $=\frac{A x 1,0009 \times 1000}{B} \times f x$ faktor pengenceran

Keterangan :

$\mathrm{A}=$ larutan EDTA yang diperlukan $(\mathrm{mL})$

$\mathrm{B}=$ sampel sebelum diencerkan $(\mathrm{mL})$

$1,0009=$ ekuivalensi antara $1 \mathrm{~mL}$ EDTA

$0,01 \mathrm{M}$ dan $1 \mathrm{mg}$ kesadahan sebagai $\mathrm{CaCO}_{3}$

$\mathrm{f}=$ faktor perbedaan antara kadar larutan EDTA 0,01 M dengan kadar larutan EDTA menurut standarisasi

\section{HASIL DAN PEMBAHASAN \\ Karakterisasi Abu Terbang Komposisi kimia abu terbang}

Hasil analisis komposisi kimia abu terbang dapat dilihat pada Tabel 1 . Komponen utama yang terkandung dalam abu terbang adalah silika dan alumina. Kandungan abu terbang mirip dengan zeolit. Oleh karena itu abu terbang dapat digunakan sebagai adsorben.
Tabel 1. Komposisi kimia abu terbang

\begin{tabular}{|c|c|}
\hline Komponen & $\%$ \\
\hline $\mathrm{SiO}_{2}$ & 39,8469 \\
\hline $\mathrm{Al}_{2} \mathrm{O}_{3}$ & 12,7389 \\
\hline $\mathrm{FeO}$ & 18,3053 \\
\hline $\mathrm{CaO}$ & 21,5784 \\
\hline $\mathrm{MgO}$ & 5,6853 \\
\hline $\mathrm{TiO}_{2}$ & 1,1439 \\
\hline $\mathrm{S}$ & 0,6714 \\
\hline $\mathrm{Na}_{2} \mathrm{O}$ & 0,5863 \\
\hline $\mathrm{MnO}$ & 0,3424 \\
\hline $\mathrm{ZnO}_{2} \mathrm{O}$ & 0,1162 \\
\hline $\mathrm{P}_{2} \mathrm{O}_{5}$ & 0,1104 \\
\hline $\mathrm{V}_{2} \mathrm{O}_{5}$ & 0,0401 \\
\hline $\mathrm{Cr}_{2} \mathrm{O}_{7}$ & 0,0008 \\
\hline
\end{tabular}

\section{Karakterisasi abu terbang}

Karakterisasi abu terbang meliputi porositas, kadar air, daya serap terhadap iodium dan daya serap terhadap biru metilen. Hasil karakterisasi biru metilen dapat dilihat pada Tabel 2.

Tabel 2. Hasil karakterisasi abu terbang

\begin{tabular}{|l|l|}
\hline \multicolumn{1}{|c|}{ Karakterisasi } & \multicolumn{1}{c|}{ Hasil } \\
\hline Porositas & $13,6056 \%$ \\
\hline Kadar air & $0,055 \%$ \\
\hline $\begin{array}{l}\text { Daya serap terhadap } \\
\text { iodium }\end{array}$ & $216,8975 \mathrm{mg} / \mathrm{g}$ \\
\hline $\begin{array}{l}\text { Daya serap terhadap } \\
\text { biru metilen }\end{array}$ & $0,3891 \mathrm{mg} / \mathrm{g}$ \\
\hline
\end{tabular}

Porositas merupakan perbandingan antara volume total ruang pori dan volume total sampel bubuk. Porositas abu terbang asal PLTU Cilacap adalah 13,6056\%. Besar kecilnya porositas tergantung pada rasio Si/Al. Rasio $\mathrm{Si} / \mathrm{Al}$ yang tinggi menunjukkan jumlah $\mathrm{Si}$ lebih besar daripada Al. Jari-jari Si (110 pm) lebih kecil daripada Al (125 pm) sehingga ukuran sel dan pori-porinya kecil (Setyawan dan Handoko, 2002). Berdasarkan hasil analisa komposisi abu terbang dapat dilihat bahwa jumlah $\mathrm{Si}$ lebih besar daripada Al sehingga rasio $\mathrm{Si} / \mathrm{Al}$ lebih tinggi. 
Kadar air abu terbang asal PLTU Cilacap sangat kecil yaitu $0,055 \%$. Abu terbang diperoleh dari pembakaran batubara pada suhu $850^{\circ} \mathrm{C}$ (Sinaro, 2003) sehingga air yang terkandung dalam batubara telah banyak menguap.

Daya serap terhadap iodium menunjukkan kemampuan abu terbang dalam menyerap molekul-molekul kecil atau zat dalam fasa cair. Sedangkan daya serap terhadap biru metilen menunjukkan kemampuan abu terbang dalam menyerap zat warna. Pada penelitian ini daya serap terhadap iodium dan biru metilen abu terbang asal PLTU Cilacap berturut-turut sebesar $216,8975 \mathrm{mg} / \mathrm{g}$ dan $0,3891 \mathrm{mg} / \mathrm{g}$.
Hal ini sejalan dengan nilai porositas yang tidak besar sehingga mempengaruhi daya adsorpsinya.

\section{Aplikasi Abu Terbang untuk Menurunkan Kasadahan Air}

Kadar kesadahan total air dari Desa Darmakradenan menunjukkan kesadahan yang cukup tinggi yaitu 467,6772 ppm sebagai $\mathrm{CaCO}_{3}$.Air sadah diadsorpsi menggunakan sistem "batch" dengan variasi waktu $0,10,30,60,90,120,150$,dan 180 menit kemudian dianalisis kesadahan totalnya menggunakan metode titrasi. Hasil yang diperoleh dapat dilihat pada Gambar 1.

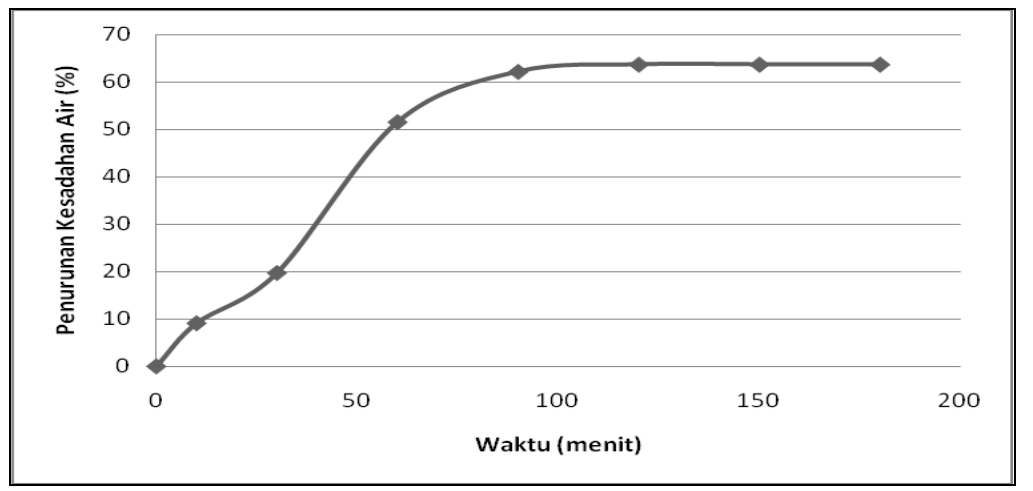

Gambar 1. Penurunan kadar kesadahan total air oleh abu terbang

Adsorpsi cenderung meningkat dengan bertambahnya waktu kontak. Setelah permukaan adsorben jenuh atau telah tertutupi semua oleh adsorbat maka adsorben tidak mampu lagi mengadsorpsi adsorbat, pada saat inilah dicapai kesetimbangan. Berdasarkan Gambar 1 diperoleh waktu kontak setimbang adalah 120 menit dengan persentase penurunan 63,6363\%. Nilai kesadahan akhir adalah $170,0644 \mathrm{ppm}$.

\section{KESIMPULAN}

Karakteristik abu terbang asal PLTU Cilacap meliputi porositas sebesar 13,6056\%, kadar air sebesar 0,055\%, daya serap terhadap iodium sebesar $216,8975 \mathrm{mg} / \mathrm{g}$, dan daya serap terhadap biru metilen sebesar $0,3891 \mathrm{mg} / \mathrm{g}$. Penuruan kesadahan air menggunakan abu terbang asal PLTU Cilacap sebesar $63,6363 \%$ dengan waktu setimbang 120 menit.

\section{UCAPAN TERIMA KASIH}

Terima kasih untuk PLTU Desa Karangkandri, Kec.Kesugihan, Kab.Cilacap Jawa Tengah serta DIPA UNSOED tahun 2008.

\section{DAFTAR PUSTAKA}

Pikiran Rakyat. 20 Februari 2006. Abu Terbang PLTU Ancam Warga Cilacap. Sumber : http://www.pikiranrakyat.com/cetak/2006/022006/20/ 0402.htm. Diakses 14 Juni 2007. 
Karakterisasi Abu Terbang PLTU Cilacap Untuk ... (Senny Widyaningsih, dkk)

Setyawan, D. dan P. Handoko. 2002. Pengaruh Perlakuan Asam, Hidrotermal, dan Impregnasi pada Zeolit Alam sebagai Pengemban Kromium dalam Preparasi Katalis. Jurnal MIPA Vol.2. No.2 Universitas Jember, Seri Sains Juli 2002. 103 - 109.

Sinaro, S.D., 2003. Tarahan, PLTU Pertama yang Ramah Lingkungan. Sumber : http : //www.sinarharapan.co.id. Diakses tanggal 19 Februari 2008.

Singh, V.V., 2005. Studies on Natural Adsorbents for The Isolation of Industrial Pollutans from Waste Samples Around Delhi. Sumber: http://www.jmi.nic.in/research.

Diakses tanggal 28 Desember 2007.
Sunaryo, V., A. K. Legowo. Pemanfaatan Fly Ash Batubara sebagai Mineral Filler pada Campuran Aspal Beton. Sumber: http;//www. digilab.petra.ac.id/adscgi/pageimage.pl/jiunkpe/s1/sip4/2 003/jiunkpe-ns-s1-2003-21. Diakses 14 Juni 2007.

Wang, S., Y.Boyjoo, A.Choueib, Z.H.Zhu. 2005." Removal of Dyes from Aqueous Solution Using Fly Ash and Red Mud". J. of Water Research. 39.129 - 138. 